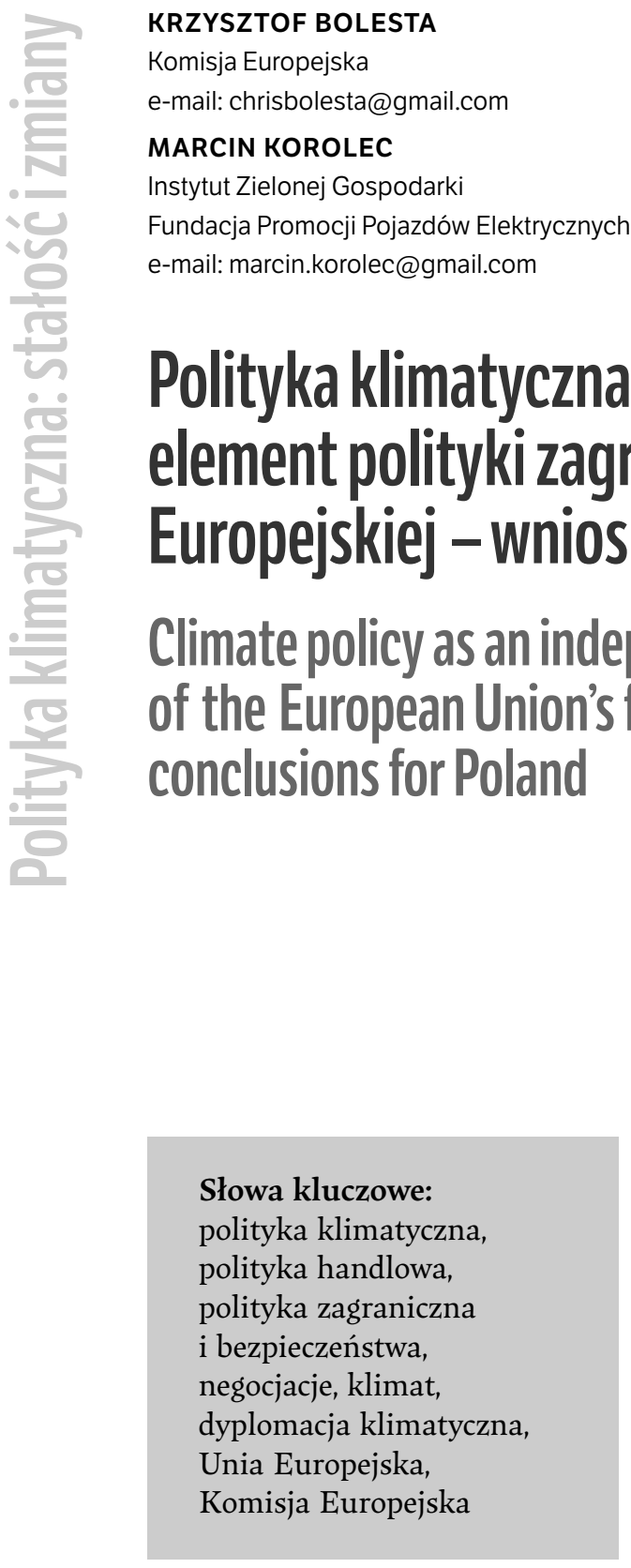

KRZYSZTOF BOLESTA

Komisja Europejska

e-mail: chrisbolesta@gmail.com

AARCIN KOROLEC

Instytut Zielonej Gospodarki

Fundacja Promocji Pojazdów Elektrycznych

e-mail: marcin.korolec@gmail.com

\title{
Polityka klimatyczna jako niezależny element polityki zagranicznej Unii Europejskiej - wnioski dla Polski
}

Climate policy as an independent element of the European Union's foreign policy: conclusions for Poland

\section{(ne}

polityka klimatyczna, polityka handlowa, polityka zagraniczna i bezpieczeństwa, negocjacje, klimat, dyplomacja klimatyczna, Unia Europejska, Komisja Europejska
Keywords:

climate policy, trade policy, foreign and security policy, negotiations, climate, climate diplomacy, European Union, European Commission 


\section{Climate policy as an independent element of the European Union's foreign policy: conclusions for Poland}

Climate and trade diplomacy are the largest multilateral negotiation processes today, involving 196 and 164 countries respectively. Consequently, climate and trade policy are also the most internationalised areas of the European Union's (EU) activity. Interestingly, both areas were developed in the EU outside the framework of the Common Foreign and Security Policy. In pursuing climate and trade policy, the European Commission has developed special mechanisms and procedures that are tailored specifically to its needs. While it is extremely difficult to agree traditional foreign policy decisions within the EU, climate diplomacy, often agreed by majority voting, is gaining importance with each new term of the European Commission. This study discusses the origins of EU climate policy and tries to answer the question of why it has gone beyond the scope of the institutional structure prepared under treaties to conduct foreign policy. This study also presents Poland's place in global climate negotiations. The authors try to show why and how the Polish administration should use the existing, practical division of competences in European climate policy and the potential accumulated in the organisation of three global climate summits in a fairly short period of time. They try to prove that climate policy is and will remain an effective tool for building the state's position in international diplomacy. 


\section{Executive summary - czyli czterdzieści lat prozą, bez pojęcia}

W sztuce Moliera Mieszczanin szlachcicem Pan Jourdain wypowiada frazę: ,...czterdzieści lat mówię prozą, nie mając o tem żywego pojęcia!". To zapewne najlepszy opis historii europejskiej dyplomacji. Tworzenie Wspólnej Polityki Zagranicznej i Bezpieczeństwa jest procesem powolnym, w którym od lat udział biorą zawodowi dyplomaci, spadkobiercy dziewiętnastowiecznego i wczesnodwudziestowiecznego myślenia w kategoriach interesu państwowego - dyplomacji przez duże „D”, w bardzo tradycyjnym rozumieniu tego słowa. Unia Europejska tymczasem - a w zasadzie można uznać, że jeszcze wcześniej Wspólnoty Europejskie - od początku swego istnienia prowadziły wspólną europejską politykę zagraniczną. Tyle tylko, że zawodowi dyplomaci albo nie zauważali tego faktu, albo uznawali, że kwestie negocjowane na szczeblu międzynarodowym są prowadzone w obszarach zbyt technicznych, aby się nimi zajmować. Handel międzynarodowy, ochrona środowiska czy ochrona klimatu były uznawane za niegodne tego, by przyjmować je za działania dyplomatyczne. Tym samym wymykały się spod jurysdykcji ministrów spraw zagranicznych, co mogło wyjść tym negocjacjom tylko na dobre. $\mathrm{W}$ innym przypadku byłyby one na pewno storpedowane przez zawodowych dyplomatów strzegących swoich pozycji w strukturze administracji rządowych, które często wynikają bardziej z tradycji niż z rzeczywistych kompetencji.

Tymczasem dyplomacja klimatyczna, czy dyplomacja handlowa, to największe procesy negocjacyjne rozmów wielostronnych, obejmujących odpowiednio 196 i 164 państwa. Część z nich, w tym na przykład małe państwa wyspiarskie jak Tuwalu czy Wyspy Marshalla, wręcz nie prowadzi polityki zagranicznej wykraczającej poza uczestnictwo w globalnej polityce klimatycznej.

Podjęcie jakichkolwiek decyzji w tak licznych gremiach wymaga nie lada wysiłku, jako że decyzje zapadają tam w drodze konsensusu. Wiele państw angażuje w procesy negocjacyjne zawodowych dyplomatów, ale decydujący głos, także w instytucjach UE, mają technokraci. To ich decyzje na międzynarodowych forach, nie dyplomatów, mają bezpośredni wpływ na legislację krajową, a w związku z tym też na to, jak żyjemy.

Dyplomacja klimatyczna w okresie przed pandemią CovID-19 to dziesiątki nieformalnych spotkań, w różnych zakątkach świata, ze stałymi w kalendarzu cyklicznymi konferencjami, m.in. w Abu-Dhabi, Davos, Tokio, 
Berlinie, Bonn czy w Nowym Yorku. Obok nich negocjacje wymagają licznych spotkań jednorazowych, organizowanych ad hoc, aby przygotować właściwe negocjacje, uszczegółowić ustalenia na szczeblu ministrów, bądź rozwiązać nieoczekiwane pojawienie się impasu w rozmowach.

Europejska dyplomacja klimatyczna rozgrywa się na dwóch płaszczyznach. Stanowisko, jakie Unia Europejska zajmuje podczas globalnych negocjacji klimatycznych, wymaga najpierw uzgodnienia na forum Rady UE, czyli między 27 państwami członkowskimi Unii Europejskiej. Uzgodniony w ten sposób mandat negocjacyjny obowiązuje na forum globalnym wszystkie państwa członkowskie. W tych rozmowach Unia Europejska jest już reprezentowana wyłącznie przez Komisję Europejską i przez kraj sprawujący w danym momencie funkcję przewodnictwa w Radzie UE (Prezydencji).

Pionierami dyplomacji europejskiej byli ministrowie ds. handlu zagranicznego. Już w Traktacie Ustanawiającym Wspólnoty Europejskie skodyfikowana została Wspólna Polityka Handlowa i podział kompetencji między Komisją i państwami członkowskimi. Z czasem kompetencje w zakresie polityki handlowej zyskał też Parlament Europejski.

W ramach obrad Światowej Organizacji Handlu (regulującej wysokości stawek celnych w handlu światowym) europejscy dyplomaci handlowi będący w większości przypadków pracownikami ministerstw odpowiedzialnych za gospodarkę - ustalają między sobą i uzgadniają z przedstawicielami Komisji Europejskiej cele negocjacyjne oraz sposoby ich osiągnięcia. Potem, już w trakcie sesji negocjacyjnych, odbywają się codzienne spotkania koordynacyjne ministrów handlu z Komisarzem UE ds. Handlu, a w razie potrzeby zwoływane są one nawet kilkakrotnie w ciągu dnia. To właśnie ta procedura, wykształcona w praktyce europejskiej dyplomacji handlowej, posłużyła jako wzór do wypracowywania wspólnego europejskiego stanowiska podczas globalnych negocjacji klimatycznych.

Inaczej niż w przypadku handlu, dyplomacja klimatyczna nie została skodyfikowana w Traktacie. Jednak podobieństwo w kształcie rozmów handlowych i klimatycznych było tak duże, że w instytucjonalnym ich urządzeniu zastosowano te same mechanizmy. Dyplomaci zajmujący się międzynarodową polityką klimatyczną w większości wywodzą się z ministerstw odpowiedzialnych za ochronę środowiska, bądź za handel zaǵraniczny, a nie z ministerstw spraw zagranicznych. Trudno ocenić, jak z wynegocjowaniem szczegółowych dokumentów będących fundamentem światowego prawa ochrony klimatu - takich jak Konwencja Klimatyczna UNFCCC, Protokół 
z Kioto - poradziliby sobie zawodowi dyplomaci. Tak czy inaczej, dzisiaj globalna polityka klimatyczna pozostaje poza ich kontrolą. Korzystając z dorobku polityki handlowej, międzynarodowe negocjacje klimatyczne wykształciły praktyczne mechanizmy podejmowania decyzji i wpłynęły na stworzenie konkretnych ram instytucjonalnych. Ram, które "wyłuskały” klimat spod parasola polityki zagranicznej i bezpieczeństwa, a umiejscowiły go $\mathrm{w}$ zbiorze spraw gospodarczych. Powoduje to ciekawy dualizm w europejskiej dyplomacji, gdzie za globalne negocjacje klimatyczne obejmujące wszystkie dziedziny gospodarki, ale też i politykę bezpieczeństwa (np. wojny klimatyczne, imigracja) odpowiada Komisarz ds. Klimatu, a nie Wysoki Przedstawiciel ds. Polityki Zagranicznej i Bezpieczeństwa. Rodzi to określone problemy, ale stwarza też okazje do budowania określonych strategii negocjacyjnych na poziomie krajowym.

\section{Polityka zagraniczna Unii Europejskiej}

Wspólna polityka zagraniczna i bezpieczeństwa UE wykuwała się od momentu utworzenia Wspólnot Europejskich powołanych do życia Traktatem paryskim $^{1}$ i Traktatami rzymskimi ${ }^{2}$. Założyciele Wspólnot dyskutowali nad sformalizowaniem współpracy politycznej i zagranicznej od początku ich istnienia, ale na konkretne ramy prawne czekać trzeba było długo.

Pierwszy raz polityka zagraniczna trafiła do traktatów UE dopiero wraz z uzgodnieniem Jednolitego Aktu Europejskiego (JAE) ${ }^{3}$ w 1986 r. Zgodnie z artykułem 7a JAE państwa członkowskie miały starać się przyjmować wspólne stanowiska w ramach gremiów międzynarodowych. Był to zapis bardzo mało zobowiązujący i bardzo szybko okazało się, że aby miał jakiekolwiek znaczenie, trzeba go uściślić.

1 Traktat paryski z 18 kwietnia 1951 r. ustanawiający Europejską Wspólnotę Węgla i Stali, dostępny w internecie [dostęp: 24 IV 2020]: 〈https://eur-lex.europa.eu/ LexUriServ/LexUriServ.do?uri=CELEX:11951K:EN:PDF $\rangle$.

2 Traktaty z 25 marca 1957 r. ustanawiające Europejską Wspólnotę Gospodarczą (EWG) oraz Europejską Wspólnotę Energii Atomowej (Euratom), dostępny w internecie [dostęp: 24 IV 2020]: <https://www.europarl.europa.eu/about-parliament/en/ in-the-past/the-parliament-and-the-treaties/treaty-of-rome $>$.

3 Jednolity Akt Europejski, Dz.U. L 169 z 29 VI 1987, s. 1-28, dostępny w internecie [dostęp: 24 IV 2020]: <https://eur-lex.europa.eu/legal-content/PL/TXT/HTML/? uri=LEGISSUM:XyO027\&from $=$ PL $>$. 
Zmiany ustrojowe w Europie Środkowo-Wschodniej, rozpad Związku Sowieckiego i Jugosławii oraz wojna w Iraku nastąpiły podczas kilku lat po wejściu w życie JAE i szybko uwypukliły niedostatek koordynacji europejskiej polityki zagranicznej. To głównie te wydarzenia popchnęły ówczesnych liderów państw członkowskich do dalszego uszczegółowienia tego obszaru współpracy.

Na mocy Traktatu z Maastricht w 1992 r. utworzono Unię Europejską podzieloną na trzy filary. W pierwszym znalazły się Wspólnoty Europejskie (w uproszczeniu współpraca gospodarcza), w drugim wspólna polityka zagraniczna i bezpieczeństwa (WPZiB), a w trzecim wspólna polityka sprawiedliwości i spraw wewnętrznych. Rozdzielenie spraw gospodarczych od zagranicznych było kompromisem, który miał uwspólnotowić dodatkową dziedzinę życia, nie zakłócając budowy rynku wewnętrznego. W praktyce oznaczało to, że obok bardziej konkretnych polityk regulowanych głównie głosem większości, stworzone zostały prawne podstawy dla polityki zagranicznej, kreowanej głównie jednomyślnie. Praktycznym symbolem tej dwoistości jest sposób procedowania spraw w ramach pierwszego i drugiego filaru UE. Podczas gdy sprawami dotyczącymi polityki zagranicznej w Radzie UE zajmują się Stali Przedstawiciele Państw Członkowskich na szczeblu ambasadorów - w ramach tzw. COREPER II (Komitet Stałych Przedstawicieli) - to sprawy dotyczące gospodarki podlegają ich zastępcom w ramach COREPER I.

W kontekście polityki klimatycznej niezwykle ciekawe jest to, że polityka zagraniczna i bezpieczeństwa UE, ustanowiona do wyrażania opinii jednym głosem i do jednomyślnego działania w sprawach zagranicznych, w praktyce nie zajmuje się globalnymi negocjacjami klimatycznymi. Równocześnie, kiedy polityka zagraniczna realizowana jest przez wyznaczonego do tego celu wysokiego urzędnika UE - Wysokiego Przedstawiciela Unii ds. Zagranicznych i Polityki Bezpieczeństwa (który jest również Wiceprzewodniczącym Komisji) oraz Europejską Służbę Działań Zewnętrznych, czyli unijną służbę dyplomatyczną - to politykę klimatyczną oraz międzynarodowe negocjacje klimatyczne na forum ONZ prowadzi Komisarz ds. Klimatu.

4 Traktat o Unii Europejskiej z 7 lutego 1992 r. Dz.U. C 191 z 29 lipca 1992 r. dostępny w internecie [dostęp: 24 IV 2020]: <https://eur-lex.europa.eu/legal-content/EN/TXT/ HTML/?uri=CELEX:11992M/TXT\&from=EN $>$. 


\section{Polityka handlowa Unii Europejskiej}

Polityka handlowa jest jedną $\mathrm{z}$ trzech dziedzin polityki (obok rolnictwa i transportu) określonych w Traktatach rzymskich ustanawiających Europejską Wspólnotę Gospodarczą (EWG) ${ }^{5}$ mianem „wspólnej”. Zawierając Traktat o EWG, państwa członkowskie zgodziły się na utworzenie między sobą unii celnej oraz prowadzenie wspólnych działań w dziedzinie handlu wobec państw trzecich i organizacji międzynarodowych.

W zarządzaniu wspólną polityką handlową kluczową rolę pełni Komisja Europejska, którą Traktaty rzymskie umocowały do prowadzenia negocjacji z GATT (General Agreement on Tariffs and Trade - obecnie Światowa Organizacja Handlu) w imieniu państw członkowskich.

Komisarz ds. Handlu, działając w imieniu Wspólnot, a dziś Unii Europejskiej, zanim podejmie konkretne działania, musi najpierw uzyskać zgodę Rady UE, czyli w praktyce zgodę ministrów ds. handlu. Mandat dla działań Komisji przyjmują oni w głosowaniu większościowym.

$\mathrm{Z}$ biegiem czasu, razem $\mathrm{z}$ rozbudowywaniem porozumień handlowych o elementy inne niż te, które odnosiły się do spraw stricte gospodarczych, zaczęły być też zatwierdzane jednomyślnie instrukcje negocjacyjne dla Komisji Europejskiej oraz umowy wynegocjowane. Dotyczy to umów o charakterze mieszanym, które zawierają także kwestie zwykle wymagające jednomyślności, np. w przypadku sektora kultury. Obecnie Komisja ma obowiązek proponować w nowych porozumieniach handlowych elementy polityki klimatycznej. To prawdopodobnie również będą umowy mieszane z mandatem zatwierdzanym jednomyślnie.

W 2007 r., wraz z przyjęciem Traktatu z Lizbony, pozycję równą Radzie uzyskał Parlament Europejski. W praktyce wzmocniło to pozycję Komisji Europejskiej, ǵdyż może ona łatwiej forsować swoje stanowisko, rozgrywając często interesy Parlamentu przeciw interesom Rady.

Sposób, w jaki Komisja operuje w imieniu państw członkowskich, prowadząc negocjacje tematów wymagających technicznej wiedzy, z dala od tradycyjnej dyplomacji, stał się doskonałym wzorcem dla rodzącej się nowej polityki wymagającej skomplikowanych globalnych negocjacji. Urzędnicy,

5 Traktat powołujący Europejską Wspólnotę Gospodarczą (Traktat rzymski) podpisany 25 marca 1957 r., dostępny w internecie [dostęp: 24 IV 2020]: <https://eur-lex. europa.eu/legal-content/FR/TXT/PDF/?uri=CELEX:11957E/TXT\&from=EN $>$. 
którzy przygotowali protokoły działania i współpracy między instytucjami oraz państwami członkowskimi w europejskich i międzynarodowych negocjacjach klimatycznych praktycznie w całości przyjęli rozwiązania polityki handlowej, a nie polityki zagranicznej i bezpieczeństwa.

\section{Polityka klimatyczna Unii Europejskiej}

Polityka zagraniczna czy ochrona środowiska, czy też ochrona klimatu, nie były od początku istnienia Wspólnot przedmiotem zainteresowania UE. W tym przypadku powód jest jednak dosyć prozaiczny. Polityka klimatyczna, jaką znamy, zaczęła się bowiem kształtować dopiero pod koniec lat osiemdziesiątych XX w. Nawet polityka ochrony środowiska, której częścią jest polityka klimatyczna, choć dziś może się to wydawać zaskakujące, trafiła do ram traktatowych UE stosunkowo późno, bo dopiero wraz z ustanowieniem $\mathrm{JAE}^{6}$, w $1986 \mathrm{r}$. Zgodnie z zapisami Tytułu VII Traktatu legislacja z zakresu ochrony środowiska jest stanowiona kwalifikowaną większością głosów. Przyjęcie ochrony środowiska w poczet polityk wspólnotowych wynikało m.in. z problemów, które powodował dynamiczny rozwój wspólnego rynku. Okazało się, że wpływ działalności gospodarczej na środowisko często ma wymiar międzynarodowy, a niektórych problemów, takich jak zanieczyszczenie wody czy powietrza, nie da się rozwiązać w pojedynkę.

Wraz z narastaniem konfliktu na linii gospodarka-środowisko rosła też presja ze strony nowego zjawiska, jakim był wpływ aktywizmu środowiskowego na mocniejsze uregulowanie ochrony środowiska na szczeblu europejskim. To dlatego m.in. została ona szerzej uregulowana wraz z przyjęciem Traktatu z Maastricht. Największym jednak orężem UE w polityce środowiskowej miała okazać się, przyjęta wraz z JAE, zasada głosowania większościowego, której do dziś nie można stosować m.in. w polityce zagranicznej czy energii (polityce ściśle związanej z działaniami na rzecz klimatu).

Za początek polityki klimatycznej w ramach UE można uznać podpisanie w 1992 r. Ramowej Konwencji Narodów Zjednoczonych w sprawie Zmian Klimatu (UNFCCC) ${ }^{7}$ podczas Konferencji Narodów Zjednoczonych na temat Środowiska i Rozwoju popularnie zwanej Szczytem Ziemi w Rio

6 Jednolity Akt Europejski...

7 UNFCCC, dostępny w internecie [dostęp: 24 IV 2020]: <https://unfccc.int/files/essential_background/background_publications_htmlpdf/application/pdf/conveng.pdf $\rangle$. 
de Janeiro. Rosnąca świadomość zmian klimatu i ich skutków oraz ustanowienie Konwencji i negocjacje Protokołu z Kioto ${ }^{8}$ podpisanego w 1997 r. pomogły w ukształtowaniu polityki klimatycznej jako mocnej odnogi polityki ochrony środowiska. Odnogi, która bardzo szybko stała się niezależnym obszarem regulacji w ramach UE.

Wdrażanie Protokołu z Kioto, który zobowiązał państwa rozwinięte do redukcji swoich emisji gazów cieplarnianych (GHG) o co najmniej 5,2 proc. $^{9}$ w całym okresie 2008-2012, w porównaniu do poziomu z $1990 \mathrm{r}$. stało się doskonałym przyczynkiem do prac nad pierwszymi narzędziami europejskiej polityki klimatycznej. Unia Europejska, tak jak dziś, składała się z państw o różnym stopniu rozwoju i wysiłki redukcyjne stanowiły różne wyzwanie dla każdego z nich. W związku z tym skorzystała ona z możliwości rozliczenia się ze zobowiązań Kioto jako grupa. Oznaczało to uzgodnienie wspólnego zobowiązania redukcyjnego dla UE na poziomie 8 proc. $^{10} \mathrm{i}$ jego podział wewnętrzny na państwa członkowskie w celu bardziej sprawiedliwego rozłożenia ciężaru. Mechanizm ten jest stosowany do dziś zarówno w odniesieniu do zobowiązań międzynarodowych wobec ONZ, jak i wewnętrznie jako podział uzgadnianych na poziomie UE celów redukcyjnych emisji $\mathrm{CO}_{2}$.

Prace nad Protokołem z Kioto, jego wdrożeniem oraz kolejne rundy międzynarodowych negocjacji klimatycznych stały się kamieniem węgielnym europejskiej polityki klimatycznej. Nie tylko były przyczynkiem do rozbudowy kompetencji klimatycznych w ramach Komisji Europejskiej. Wpłynęły też na ciekawą obudowę instytucjonalną i niejako wyłom w traktatach. Od 2010 r. w ramach Komisji Europejskiej funkcjonuje stanowisko komisarza ds. klimatu. Osoba piastująca to stanowisko, podobnie jak komisarz ds. handlu, prowadzi działania obejmujące znaczący zakres polityki zagranicznej. To właśnie komisarz odpowiedzialny za klimat uczestniczy w globalnych negocjacjach $\mathrm{w}$ ramach oNZ i reprezentuje podczas tych rozmów

8 Protokół z Kioto, dostępny w internecie [dostęp: 24 IV 2020]: <https://unfccc.int/ documents/2409>.

9 Kyoto Protocol, European Commission, dostępny w internecie [dostęp: 24 IV 2020]: 〈https://ec.europa.eu/commission/presscorner/detail/en/MEMO_04_43〉.

10 Pierwszy okres rozliczeniowy protokołu z Kioto (2008-2012), European Commission, dostępny w internecie [dostęp: 24 IV 2020]: <https://ec.europa.eu/clima/policies/ strategies/progress/kyoto_1_pl>. 
państwa członkowskie. Stanowiska UE uzgadniane są w sposób podobny do tego stosowanego $\mathrm{w}$ ramach polityki handlowej, gdzie decydujące słowo ma Komisja Europejska. Jedynym wyjątkiem dotyczącym polityki klimatycznej jest to, że instrukcje dla komisarzy przyjmowane są jednomyślnie. Wysoki Przedstawiciel UE ds. Polityki Zagranicznej i Bezpieczeństwa nie tylko nie prowadzi negocjacji klimatycznych, ale nawet nie bierze w nich udziału. Ogromny obszar rzeczywistości gospodarczej, i nie tylko (elementy klasycznej polityki zagranicznej i bezpieczeństwa), wymyka się w ten sposób spod jurysdykcji urzędników zajmujących się właśnie tymi sprawami i są stanowione w inny sposób niż przewidywałyby w tej sytuacji traktaty.

Negocjacje protokołu z Kyoto, nakładającego określone zobowiązania redukcji gazów cieplarnianych, wymagały od Komisji Europejskiej podjęcia określonych działań regulacyjnych. To właśnie tak rodziła się Europejska polityka klimatyczna. Dziś europejską politykę w obszarze przeciwdziałania zmianom klimatu można podzielić na dwa filary. Pierwszy z nich to sfederalizowany, ogólnoeuropejski system handlu uprawnieniami do emisji $\mathrm{CO}_{2}$ (EUETS) ${ }^{11}$ wdrożony jako rynkowy mechanizm pozwalający na osiągnięcie uzgodnionych redukcji $\mathrm{CO}_{2}$ z dużych instalacji przemysłowych i energetycznych. System objął wszystkie państwa UE, a co ciekawe, przy pracach nad jego ustanowieniem została wykorzystana zasada większościowego głosowania wprowadzona po raz pierwszy przez JAE w obszarze ochrony środowiska. Była to reakcja Komisji Europejskiej na nieudaną próbę przyjęcia europejskiego podatku energetycznego, który nie doszedł do skutku z powodu obowiązku jednomyślnego głosowania ze względu na osadzenie $\mathrm{w}$ polityce podatkowej. To właśnie od tego momentu wszystkie narzędzia europejskiej polityki klimatycznej były osadzane na traktatowych podstawach polityki ochrony środowiska i w związku z tym nie wymagały jednomyślności przy głosowaniach.

EUETS zawiera ważny komponent współpracy międzynarodowej i jest przedmiotem intensywnej promocji ze strony KE. Podstawą wysiłków redukcji emisji $\mathrm{CO}_{2}$ jest bowiem konieczność globalnej partycypacji oraz zachowanie równych warunków prowadzenia działalności gospodarczej

11 Dyrektywa 2003/87/WE Parlamentu Europejskiego i Rady z dnia 13 października 2003 r. ustanawiająca system handlu przydziałami emisji gazów cieplarnianych w Unii oraz zmieniająca dyrektywę Rady 96/61/WE, Dz.U. L 275 z 25.10.2003, s. 32, tekst jednolity z 8 IV 2018 r. 
między państwami (level playing field). Redukcje UE będą mieć tym większe znaczenie i będą efektywniejsze kosztowo, im więcej innych państw zdecyduje się na przyjęcie ambitnych celów regulacyjnych. Promowanie europejskiego rozwiązania, jakim stał się EUETS, jest sposobem UE na zwiększanie globalnej partycypacji w wysiłku redukcyjnym. Również i tu najważniejszą rolę pełni ta część KE, która jest odpowiedzialna za klimat, a nie Wysoki Przedstawiciel ds. Polityki Zagranicznej i Bezpieczeństwa.

Drugi filar polityki wewnętrznej strategii ochrony klimatu obejmuje wszystkie emisje gazów cieplarnianych nieobjęte EUETs i dlatego nazwany jest w uproszczeniu systemem non-ETs. W przypadku tych emisji - pochodzących m.in. z sektorów rolnictwa, transportu, budownictwa, odpadów czy gospodarstw domowych - nie ma konkretnych narzędzi redukcyjnych, a sposoby ograniczenia emisji pozostawiane są państwom członkowskim ${ }^{12}$. Ten filar polityki klimatycznej nie ma aspektu międzynarodowego.

Polityka klimatyczna $w$ ramach instytucji UE sukcesywnie zyskuje na znaczeniu. W 2010 r. ustanowione zostało po raz pierwszy stanowisko komisarza ds. klimatu, które objęła Connie Hedegaard. W kolejnej KE stanowisko komisarza odpowiedzialnego za klimat zostało wzmocnione o obszar polityki energetycznej. Od 2019 r., kiedy na czele KE stanęła Ursula von der Leyen, komisarz odpowiedzialny za "tekę" klimatyczną Frans Timmermans jest zarazem wiceprzewodniczącym KE nadzorującym wdrożenie tzw. Europejskiego Zielonego Ładu (EZŁ). Zielony Ład jest horyzontalnym planem gospodarczym zakładającym osiągnięcie przez UE neutralności klimatycznej do 2050 r. Oznacza to, że w 2050 r. emisje $\mathrm{CO}_{2}$ w Europie nie będą mogły być wyższe niż ilość $\mathrm{CO}_{2}$, jaka zostanie pochłonięta np. przez lasy, lub wychwycona i zmagazynowana pod ziemią, czy w postaci produktów.

Europejski Zielony Ład (EZŁ) jest też kolejną odsłoną strategii negocjacyjnej KE polegającej na dawaniu przykładu (leading by example) w celu zmobilizowania innych stron negocjacji do ambitnych działań. W przeszłości ta strategia się nie sprawdzała, a najważniejsi partnerzy UE nie jeden

12 Rozporządzenie Parlamentu Europejskiego i Rady (UE) 2018/842 z dnia 30 maja 2018 r. w sprawie wiążących rocznych redukcji emisji gazów cieplarnianych przez państwa członkowskie od 2021 r. do 2030 r. przyczyniających się do działań na rzecz klimatu w celu wywiązania się z zobowiązań wynikających z Porozumienia paryskiego oraz zmieniające rozporządzenie (UE) nr 525/2013, OJ L 156/26 z 19 VI 2018 r. 
raz zostawiali ją z podjętymi jednostronnie ambitnymi zobowiązaniami. Z założenia EZŁ ma być jednak inny niż poprzednie próby dawania przykładu ambicji z tego powodu, że UE chce wykorzystać zieloną transformację gospodarki do upowszechnienia stosowania energii ze źródeł odnawialnych i tym samym ograniczyć import paliw kopalnych oraz wyznaczenia światowych standardów, tak jak udaje się jej to w innych dziedzinach (np. regulacje dotyczące ochrony danych osobowych czy eco designn). Mający doprowadzić do radykalnego obniżenia emisji EZŁ powinien nie tylko posłużyć do zadeklarowania nowych celów redukcyjnych na arenie międzynarodowej. $\mathrm{Ma}$ on przede wszystkim pozwolić na wypromowanie europejskich technologii i firm, które mogłyby zostać globalnymi liderami. W celu ochrony podmiotów wprowadzających często droższe, niskoemisyjne rozwiązania, KE ma zaproponować tzw. carbon border adjustment mechanism, który ma pełnić funkcję cła na produkty pochodzące z państw niestosujących podobnych do europejskich narzędzi ochrony klimatu. Taki ruch jeszcze bardziej zbliży europejską politykę klimatyczną do polityki handlowej.

\section{Międzynarodowe negocjacje klimatyczne}

Globalne negocjacje klimatyczne odbywają się w ramach wspomnianej Ramowej Konwencji Narodów Zjednoczonych ws. Zmian Klimatu (UNFCCC) i toczą się nieprzerwanie od 1992 r. Celem Konwencji jest zapewnienie stabilizacji emisji gazów cieplarnianych na poziomie bezpiecznym dla środowiska i ludzi. Ratyfikowało ją 197 stron (196 państw i jedna organizacja regionalna - Unia Europejska), co oznacza, że obok międzynarodowych negocjacji handlowych, rozmowy klimatyczne są największym procesem wielostronnych negocjacji w ramach Organizacji Narodów Zjednoczonych.

Konwencja klimatyczna, jak i późniejsze umowy międzynarodowe, dla których jest ona fundamentem, np. Protokół z Kioto, podzieliły świat na dwie grupy - państwa rozwinięte i rozwijające się. Na państwa rozwinięte zostały nałożone zobowiązania redukcyjne. Państwa natomiast rozwijające się, do których zaliczają się np. Chiny, Katar czy Indie, nie muszą podejmować żadnych zobowiązań. Jest to niezwykle ważne, bo mimo wielu zmian w gospodarce międzynarodowej, w globalnych negocjacjach klimatycznych państwa wciąż bronią swoich miejsc zdefiniowanych na początku lat dziewięćdziesiątych ubiegłego wieku. 
Negocjując Protokół z Kioto, UE optowała za wyższymi obowiązkami redukcyjnymi niż ostatecznie uzgodnione, a sama zgodziła się na największe zobowiązania (8 proc. względem średniej dla państw rozwiniętych na poziomie 5,2 proc.). Co więcej, mimo że Protokołu nie ratyfikowały Stany Zjednoczone, a z porozumienia wycofała się Kanada, to Europa dotrzymała swoich zobowiązań redukcyjnych, ratując tym samym pierwszą globalną umowę klimatyczną i podtrzymując zarazem proces międzynarodowych negocjacji klimatycznych.

Można powiedzieć, że sytuacja wokół negocjacji oraz podczas realizacji Protokołu z Kioto pokazywała jak w soczewce wszelkie problemy globalnych negocjacji klimatycznych, które do dziś są aktualne. Pozycje na szachownicy interesów, zajęte wówczas przez poszczególne strony, nie uległy również znaczącej zmianie. Państwa UE od początku procesu były jego motorem i adwokatem $\mathrm{w}$ zakresie wygórowanych ambicji redukcji emisji oraz pomocy państwom rozwijającym się. Inne państwa z grupy rozwiniętych odgrywały natomiast rolę hamulcowych. USA, Kanada, Australia i Japonia rzadko oferowały w negocjacjach coś więcej niż niezbędne minimum. Taki wyjściowy podział ról sprawił, że zręby kompromisu są ustalane na linii UE-państwa rozwijające się, a reszta dołącza później. Jeśli jakieś istotne w negocjacjach państwo „wychodzi ze swej roli”, ma to zwykle ogromne konsekwencje dla wyników. Można to zaobserwować na podstawie kilku przykładowych sesji negocjacyjnych UNFCCC.

\section{Kopenhaga}

Doroczny szczyt globalnych negocjacji klimatycznych UNFCCC (tzw. COP Conference of the Parties) odbywał się w Kopenhadze w 2009 r. Miejsce rozmów odgrywa w polityce klimatycznej określone znaczenie, jako że wszystkie sesje negocjacyjne odbywające się $\mathrm{w}$ Europie wiążą się z dodatkową presją i oczekiwaniami ze strony państw rozwijających się. Tym niemniej dla wielu, zwłaszcza europejskich uczestników Konferencji, cop w Kopenhadze wyznaczył jeszcze wyższy niż zazwyczaj poziom oczekiwań. Celem było wynegocjowanie pierwszej umowy międzynarodowej zawierającej powszechnie obowiązujące, wiążące cele redukcji emisji gazów cieplarnianych, które pozwoliłyby zatrzymać wzrost globalnej temperatury do maksymalnie $2^{\circ} \mathrm{C}$.

Przygotowania do negocjacji z punktu widzenia UE wygląadały bardzo obiecująco. Współpraca Niemiec i Francji doprowadziła do przyjęcia $\mathrm{w}$ rekordowo krótkim czasie jedynego $\mathrm{w}$ swoim rodzaju i niezwykle 
ambitnego pierwszego pakietu energetyczno-klimatycznego ${ }^{13}$. Celem był rozwój energiii ze źródeł odnawialnych, poprawa efektywności energetycznej oraz redukcja emisji $\mathrm{CO}_{2}$ o 20 proc. - zadania wyznaczone na $2020 \mathrm{r}$. Elementem pakietu stał się też zreformowany Europejski System Handlu Emisjami (EUETS), czyli podstawowe narzędzie redukcji emisji w Europie. Uzbrojona w te narzędzia, podjęte we własnym gronie i niezależnie od procesu międzynarodowego, delegacja UE była przekonana, że zarazi swoim entuzjazmem inne państwa. Problem jednak polegał na tym, że w trakcie negocjacji w Unii Europejskiej można było przeforsować rozwiązania, nie uwzględniając interesów części państw, np. tych które weszły do ugrupowania w 2004 roku. Podobna metoda nie zadziałała natomiast na arenie negocjacji globalnych. Kontrproduktywne okazało się także odkrycie przez UE kart przed rozpoczęciem rozmów. Od przyjętych celów nie było odwrotu, a globalni partnerzy domagali się dodatkowych koncesji.

Zgodnie z Konwencją Klimatyczną państwa rozwijające się nie są zobowiązane do podejmowania wysiłków redukcji emisji. W związku z tym, nie musiały i nie chciały być one związane umową międzynarodową, która w sposób jednakowy, od strony prawnej, zobowiązywałaby wszystkie kraje na świecie.

To właśnie w Kopenhadze UE po raz pierwszy odsłoniła w takiej skali swoje niedostatki dyplomacji klimatycznej. Rotacyjne przewodnictwo w Radzie UE pełniła wówczas Szwecja, a gospodarzem rozmów była Dania. Oba państwa, mimo dyplomatycznych wysiłków, nie były w stanie przekonać wystarczającej liczby stron do ambitnego porozumienia w Kopenhadze. Historycznym momentem rozmów stało się, dotąd niespotykane w ramach rozmów COP, przekazanie poszukiwania kompromisu na szczebel szefów państw i rządów. Ostatecznym ciosem dla gospodarzy, a przy okazji dla całej UE, było uzgodnienie kompromisowego tekstu Porozumienia kopenhaskiego ${ }^{14}$ przez przywódców Stanów Zjednoczonych oraz państw BRICS (Brazylia, Rosja, Indie, Chiny i RPA).

132020 climate \& enerǵy package, European Commission, dostępny w internecie [dostęp: 24 IV 2020]: 〈https://ec.europa.eu/clima/policies/strategies/2020_en>.

14 Copenhagen Accord The Heads of State, Heads of Government, Ministers, and other heads of delegation present at the United Nations Climate Change Conference 2009 in Copenhagen, UN Climate Change, dostępny w internecie [dostęp: 24 IV 2020]: 〈http://unfccc.int/resource/docs/2009/cop15/eng/lo7.pdf〉. 
Fiasko Kopenhagi wynikało $\mathrm{z}$ braku zrozumienia podstawowych mechanizmów prawnych rządzących wielostronnymi negocjacjami na arenie ONZ. Ostry konflikt między państwami rozwiniętymi i rozwijającymi się podczas Konferencji w Kopenhadze, mimo przyjęcia dokumentu końcowego, doprowadził do ogromnej utraty zaufania między stronami i zahamowania na dwa lata, do czasu COP17 w Durbanie, jakichkolwiek rozmów o globalnym porozumieniu klimatycznym.

W efekcie załamania globalnych rozmów klimatycznych w Kopenhadze, poza Unią Europejską żaden kraj nie był zobowiązany do podejmowania jakichkolwiek wysiłków redukcji emisji gazów cieplarnianych. Szansa na osiągnięcie globalnego porozumienia została odsunięta w czasie, a przyjęte przez UE jednostronne zobowiązania wykreowały ryzyko ucieczki emisji z Europy oraz utraty konkurencyjności europejskiego przemysłu w globalnym handlu.

\section{Durban}

COP17 w Durbanie odbywał się zimą $2011 \mathrm{r}$. i przypadł na okres polskiego przewodnictwa w Radzie UE, czyniąc polskich przedstawicieli współodpowiedzialnymi za uzgadnianie i prezentację na globalnym forum stanowiska Unii Europejskiej. Polska postawiła sobie za zadanie powtórne doprowadzenie do prac nad nowym projektem globalnej umowy klimatycznej. W wyniku dwutygodniowych obrad udało się uzgodnić parametry nowej globalnej umowy klimatycznej. Państwa członkowskie Konwencji Klimatycznej uzgodniły, że rozpoczynają negocjacje „umowy międzynarodowej, [...] prawnie zobowiązującej wszystkie strony Konwencji Klimatycznej i zgodnie z jej zapisami"15. Uzgodnienie tego niewinnego, zdawałoby się zdania było głównym osiągnięciem cop w Durbanie. W rozmowach bardzo pomogło to, że toczyły się one na terytorium państwa rozwijającego się, a stanowisko UE koordynowało państwo dobrze znające trudności wynikające $\mathrm{z}$ radykalnej transformacji gospodarki.

15 Essential Background - Durban outcomes, UN Climate Change, dostępne w internecie [dostęp: 24 IV 2020]: 〈https:/unfccc.int/process/conferences/the-big-picture/ milestones/outcomes-of-the-durban-conference $>$. 


\section{Warszawa}

To, w jaki sposób można pogodzić wiążące cele z koniecznością uznania różnicy w rozwoju między państwami, pokazały globalne negocjacje w Warszawie. Właśnie podczas COP19 na Stadionie Narodowym negocjatorzy położyli fundamenty pod Porozumienie paryskie.

Uzgodniono wówczas, że państwa członkowskie Konwencji Klimatycznej w ramach przyszłej umowy będą podejmowały dobrowolne zobowiązania, których suma ma doprowadzić do zatrzymania zmian klimatycznych ${ }^{16}$. Taki wynik rozmów okazał się możliwy tylko dzięki współdziałaniu dyplomatów europejskich, w tym Komisji Europejskiej oraz zaangażowaniu Stanów Zjednoczonych i Chin.

W Warszawie też po raz pierwszy została w pełni zaprezentowana siła europejskiej dyplomacji klimatycznej, która wynika ze współdziałania instytucji 27 państw członkowskich i jest wspomagana przez historyczne powiązania niektórych z nich. Sieci wpływów brytyjskich, francuskich, hiszpańskich czy portugalskich na całym świecie, ale też polskich w Europie Środkowo-Wschodniej i państwach byłego Związku Sowieckiego, są ważnymi instrumentami oddziaływania i okazały się kluczowe dla uzgodnień COP w Warszawie, gdzie jak w przypadku każdej konferencji coP decyzje zapadały w drodze jednomyślności.

Dobra współpraca w ramach UE i zaangażowanie Komisji Europejskiej pomogło w uzgodnieniu kompromisu, ale nie byłoby to zapewne możliwe, gdyby nie konstruktywna postawa Chin i Stanów Zjednoczonych, które brały aktywny udział w poszukiwaniu rozwiązań. COP w Warszawie pokazał też, że nawet negocjacje, które odbywają się w Europie, mogą przebiegać konstruktywnie i kończyć się sukcesem, co potwierdziło potem podpisanie Porozumienia paryskiego.

Organizacja COP w Warszawie i sukces konferencji pomogły zbudować kapitał negocjacyjny Polski na arenie UE oraz w skali globalnej. Konstruktywna postawa polskich negocjatorów, wynikająca z dobrej współpracy dyplomacji i ekspertów, także przejrzystość wobec partnerów europejskich i sekretariatu UNFCCC, pozwoliły Polsce wejść na kilka

16 Warsaw Outcomes, UN Climate Change, dostępne w internecie [dostęp: 24 IV 2020]: <https://unfccc.int/process/conferences/the-big-picture/milestones/outcomesof-the-warsaw-conference $>$. 
lat do ekstraklasy globalnej polityki klimatycznej, a zarazem przedsionka wielkiej geopolityki. Niestety osiągnięcie to nie zostało w pełni wykorzystane.

\section{Dyplomacja klimatyczna Unii Europejskiej}

Polityka klimatyczna jest, obok handlu, najbardziej umiędzynarodowionym obszarem działania UE. Co więcej, doświadczenia wyniesione z realizacji polityki handlowej sprawiły, że negocjacje klimatyczne, wymagające równie technicznej wiedzy i będące de facto częścią polityki gospodarczej, prowadzone są w bardzo podobny sposób do negocjacji handlowych. Komisja wypracowała metody działania i uporządkowała relacje między instytucjami i państwami członkowskimi, stosując praktyki znane właśnie z negocjacji handlowych. W ten sposób globalną politykę klimatyczną prowadzi się niezależnie od europejskiej polityki zagranicznej i bezpieczeństwa. Widoczna jest $w$ tym przypadku odrębność instytucjonalna i proceduralna. Znamienne, że państwa członkowskie akceptują taki podział obowiązków, a dyplomacją klimatyczną kieruje Komisarz ds. Klimatu, a nie Wysoki Przedstawiciel UE ds. Polityki Zagranicznej i Bezpieczeństwa. Dyplomację, która zyskuje na znaczeniu z każdą kolejną kadencją KE.

Dyplomacja klimatyczna wiąże się nie tylko z dominującą rolą Komisji Europejskiej w globalnych negocjacjach. Proponuje ona co prawda linię negocjacji, ale często wynika wprost $\mathrm{z}$ wewnętrznej polityki klimatycznej UE ustalanej wciąż jednomyślnie. Co jest równie istotne, to włączanie pod skrzydła dyplomacji klimatycznej wciąż nowych dziedzin polityki UE. Oferta negocjacyjna Komisji podczas rozmów klimatycznych na forum OzN obejmuje często takie elementy jak finansowanie państw rozwijających się i pomoc gospodarczą, transfer technologii czy wymianę naukową. Negocjacje klimatyczne stają się z każdym rokiem bardziej kompleksowe, obejmują ustawicznie nowe dziedziny życia, nie tylko gospodarczego, a w związku z tym pod parasol polityki klimatycznej KE trafiają nowe kompetencje. Coraz trudniejsze negocjacje i skomplikowane porozumienia wymuszają przygotowanie oferty łączonej, obejmującej wiele dziedzin. Wydaje się, że taki rozwój rozmów klimatycznych może doprowadzić do sytuacji, w której negocjacje te mają w praktyce większe znaczenie niż negocjacje handlowe. Nie tylko na szczeblu Komisji, ale również na poziomie państw członkowskich. 


\section{Podsumowanie}

Strategicznym celem Polski $\mathrm{w}$ globalnych negocjacjach klimatycznych do 2015 r. było doprowadzenie do zawarcia umowy obejmującej wszystkie państwa konwencji klimatycznej. Obowiązujące bowiem do $2020 \mathrm{r}$. umowy globalne do działań zobowiązywały de facto jedynie Unię Europejską. Taka sytuacja nie dawała szans na prawdziwą ochronę klimatu, ale też wnosiła poważne zagrożenie dla nierównomiernych obciążeń, które prowadziłyby do zaburzenia równowagi na światowej arenie gospodarczej i przemysłowej. Zawarcie globalnej Umowy klimatycznej zmniejsza to ryzyko, lecz go nie eliminuje. Aby dopilnować odpowiedniej implementacji umowy, Polska musi włączyć się w konstruktywne kształtowanie europejskiej polityki klimatycznej. Tylko w ten sposób będzie mogła uczestniczyć jako aktywny gracz globalnej dyplomacji klimatycznej. W przypadku każdego państwa UE tych dwóch obszarów nie da się po prostu rozgraniczyć, gdyż jeden wynika z drugiego.

Polska mozolnie pracowała nad awansem do elity światowej dyplomacji klimatycznej oraz pełniła aktywną rolę w kształtowaniu europejskiej dyplomacji klimatycznej. Krokami milowymi w tym procesie okazały się kolejne globalne sesje negocjacyjne, które odbyły się w Polsce - CoP14 w Poznaniu, COP19 w Warszawie i COP24 w Katowicach, a także polska Prezydencja w Unii Europejskiej w $2011 \mathrm{r}$.

Największy wzrost prestiżu Polski wiąże się właśnie z okresem między przewodnictwem Polski w radzie UE (2011 r.) i COP $20 \mathrm{w}$ Limie (2014 r.). Były to lata intensywnego zaangażowania Polski w globalną i europejską politykę klimatyczną. Prezydencja w UE pozwoliła na przewodnictwo unijnej delegacji podczas COP17 w Durbanie, potem przygotowania do COP19 w Warszawie, Prezydencja rozmów UNFCCC i wreszcie przekazanie przewodnictwa Peru zakończone konferencją w Limie - to trzy lata szczególnej prężności i dużego wkładu polskich negocjatorów i dyplomatów w międzynarodową politykę klimatyczną, która nie ogranicza się do rozmów o redukcjach $\mathrm{CO}_{2}$, ale niesie ze sobą większe zaangażowanie w geopolitykę, np. w ramach Zgromadzenia Ogólnego ONZ, Szczytu Liderów organizowanego przez Sekretarza Generalnego onZ, Zielonego Trójkąta Weimarskiego czy Major Economies Forum - cyklu spotkań Ministrów ds. Klimatu, Grupy G20, jedynej formacji G20, której Polska była pełnoprawnym uczestnikiem.

Wykształceni przez tak intensywny okres negocjacji klimatycznych polscy eksperci są cenieni przez inne delegacje europejskie oraz na arenie globalnej. Ich pozycja wynika z merytorycznego przygotowania, które 
umożliwiło konsekwentne inwestowanie $\mathrm{w}$ budowę zespołu specjalistów na szczeblu centralnym oraz stworzenia im dogodnych warunków do pracy, niezależnie od aktualnej polityki w kraju. Bardzo pomocny, zwłaszcza $\mathrm{w}$ dialogu z państwami rozwijającymi się, jest sukces transformacji po 1989 roku, jaka miała miejsce w Polsce zarówno pod względem środowiskowym, jak i gospodarczym, zwłaszcza wraz ze wstąpieniem do Unii Europejskiej. Czyni on Polskę wiarygodnym partnerem, dodatkowo nieuwikłanym w globalną politykę historyczną.

Aby w pełni wykorzystać potencjał wykreowany przez zespół polskich negocjatorów klimatycznych potrzebne są dwie rzeczy. Po pierwsze, Polska powinna zmienić miejsce, które zajmuje w europejskiej debacie klimatycznej. Bez zadeklarowania neutralności klimatycznej i wyjścia z pozycji państwa blokującego większość nowych inicjatyw klimatycznych, niemożliwe będzie czerpanie korzyści z dyplomacji klimatycznej. Polska musi pokazać, że nie tylko rozumie globalne negocjacje, ale też jest konstruktywnym członkiem europejskiej rodziny. Nawet lekka zmiana kursu może dać Polsce mandat do zajęcia mocniejszej pozycji w globalnych negocjacjach klimatycznych. Każda sesja rozmów UNFCcC to misterny podział ról między Komisję i główne państwa członkowskie. Polska ma kompetencje, aby pełnić takie role, jak to pokazywała dotychczas, wykonując kilkukrotnie z powodzeniem rolę gospodarza Konferencji Klimatycznych.

Po drugie, polityka klimatyczna powinna zostać uznana za jeden z priorytetów polskiej polityki zagranicznej. Europejska polityka klimatyczna to istotny element polityki rozwoju. Kapitał wykreowany w czasie międzynarodowych negocjacji klimatycznych, mógłby, i powinien być wykorzystany jako element krajowej dyplomacji klimatycznej. Na przykładzie tego, jak wygląda europejska dyplomacja klimatyczna, można wykreować narzędzia polityki zagranicznej, które pozwolą na promocję polskich firm, technologii i na budowanie nowoczesnej dyplomacji ekonomicznej połączonej z pomocą rozwojową, której znaczenie tylko będzie wzrastać w polskim budżecie.

\section{Bibliografia}

2020 climate \& enerǵy package, European Commission, dostępny w internecie [dostęp: 24 IV 2020]: 〈https://ec.europa.eu/clima/policies/strategies/2020_en〉.

Copenhagen Accord The Heads of State, Heads of Government, Ministers, and other heads of delegation present at the United Nations Climate Change Conference 2009 in Copenhagen, UN Climate Change, dostępny w internecie [dostęp: 24 IV 2020]: 〈http://unfccc.int/resource/docs/2009/cop15/eng/lo7.pdf $\rangle$. 
Dyrektywa 2003/87/WE Parlamentu Europejskiego i Rady z dnia 13 października 2003 r. ustanawiająca system handlu przydziałami emisji gazów cieplarnianych w Unii oraz zmieniająca dyrektywę Rady 96/61/WE, Dz.U. L 275 z 25.10.2003, s. 32, tekst jednolity z 8 IV 2018 r.

Essential Background - Durban outcomes, UN Climate Change, dostępne w internecie [dostęp: 24 IV 2020]: 〈https:/unfccc.int/process/conferences/the-big-picture/ milestones/outcomes-of-the-durban-conference $>$.

Jednolity Akt Europejski, Dz.U. L 169 z 29 VI 1987, s. 1-28, dostępny w internecie [dostęp: 24 IV 2020]: 〈https://eur-lex.europa.eu/legal-content/PL/TXT/HTML/? uri=LEGISSUM:xyOO27\&from $=\mathrm{PL}\rangle$.

Kyoto Protocol, European Commission, dostępny w internecie [dostęp: 24 IV 2020]: 〈https://ec.europa.eu/commission/presscorner/detail/en/MEMO_04_43〉.

Pierwszy okres rozliczeniowy protokołu z Kioto (2008-2012), European Commission, dostępny w internecie [dostęp: 24 IV 2020]: UNFCCC, dostępny w internecie [dostęp: 24 IV 2020]: <https://unfccc.int/files/essential_background/background publications_htmlpdf/application/pdf/conveng.pdf $\rangle$.

Protokół z Kioto, dostępny w internecie [dostęp: 24 IV 2020]: <https://unfccc.int/ documents/2409>.

Rozporządzenie Parlamentu Europejskiego i Rady (UE) 2018/842 z dnia 30 maja 2018 r. w sprawie wiążących rocznych redukcji emisji gazów cieplarnianych przez państwa członkowskie od 2021 r. do 2030 r., przyczyniających się do działań na rzecz klimatu w celu wywiązania się z zobowiązań wynikających z Porozumienia paryskiego oraz zmieniające rozporządzenie (UE) nr 525/2013, OJ L $156 / 26$ z 19 VI 2018 r.

Traktat o Unii Europejskiej z 7 lutego 1992 r. Dz.U. C 191 z 29 lipca 1992 r. dostępny w internecie [dostęp: 24 IV 2020]: 〈https://eur-lex.europa.eu/legal-content/EN/ TXT/HTML/?uri=CELEX:11992M/TXT\&from=EN $>$.

Traktat paryski z 18 kwietnia 1951 r. ustanawiający Europejską Wspólnotę Węgla i Stali, dostępny w internecie [dostęp: 24 IV 2020]: <https://eur-lex.europa.eu/ LexUriServ/LexUriServ.do?uri=CELEX:11951K:EN:PDF $\rangle$.

Traktat powołujący Europejską Wspólnotę Gospodarczą (traktat rzymski) podpisany 25 marca 1957 r., dostępny w internecie [dostęp: 24 IV 2020]: 〈https://eur-lex.europa.eu/legal-content/FR/TXT/PDF/?uri=CELEX:11957E/TXT\&from=EN $\rangle$.

Traktaty z 25 marca 1957 r. ustanawiające Europejską Wspólnotę Gospodarczą (EWG) oraz Europejską Wspólnotę Energii Atomowej (Euratom), dostępny w internecie [dostęp: 24 IV 2020]: 〈https://www.europarl.europa.eu/about-parliament/ en/in-the-past/the-parliament-and-the-treaties/treaty-of-rome $\rangle$.

UNFCCC, dostępny w internecie [dostęp: 24 IV 2020]: 〈https://unfccc.int/files/essential_ background/background_publications_htmlpdf/application/pdf/conveng.pdf $\rangle$. Warsaw Outcomes, UN Climate Change, dostępne w internecie [dostęp: 24 IV 2020]: $<$ https://unfccc.int/process/conferences/the-big-picture/milestones/outcomesof-the-warsaw-conference $>$. 